\title{
O filósofo e o poeta
}

\author{
Lilia Silvestre Chaves \\ Universidade Federal do Pará. Belém, Pará, Brasil
}

Como documento humano, creio ser a poesia insuperável

(Mário Faustino, 1977, p. 40).

A Poesia como dom, seja como Mito ou como linguagem poética,

é a entrada ou o limiar da Filosofia

(Benedito Nunes, 2007, p. 4).

\section{Ora pois, Sibila...}

Em novembro de 2008, Benedito Nunes sentou-se à frente de um grupo de alunos do mestrado em Letras Estudos literários, da Universidade Federal do Pará, no Auditório Francisco Paulo Mendes (Instituto de Letras e Comunicação), para comentar um poema de Mário Faustino. No dia da morte de Mário Faustino (quarenta e seis anos depois), os três amigos inseparáveis na Belém do final dos anos 1940 (Mário, Benedito e Mendes) reuniramse simbolicamente. Era o I Simpósio Olhares sobre o Poético, organizado pela turma da disciplina "Estudos do Poema", que homenageava o poeta piauiense-paraense Mário Faustino. Como professora da turma, convidei-o e pedi-lhe que fizesse a leitura crítica de "Nam Sybillam...", que eu sabia ser um dos seus poemas preferidos. Ele aceitou, com bastante entusiasmo, e mostrou, para a audiência privilegiada daquele dia, porque é considerado um dos nossos mais brilhantes professores e críticos literários. Transcrevo aqui apenas o início da aula:
Eu vou tentar examinar um poema do Mário, um dos sete sonetos de amor e morte que começa pela expressão Nam Sibyllam. É de notar que essa expressão não está entre aspas. Isso é muito significativo. Talvez seja atestado de que Mário tomou a figura da Sibila, fazendo dela, que é mulher, uma intérprete, conforme nós vamos ver a importância das Sibilas como profetisas desde o mundo antigo.

Não está aspeada a expressão, o que leva a crer que seja do próprio poeta, como se ele tivesse que extrair essa expressão de um texto próximo, como se proviesse de texto mais próximo das tradições que Mário honrou, que foi a tradição greco-latina, referente ao que chamamos de Clássico: os poemas de Homero (...), que tiveram seus derivados latinos, os poemas de Virǵlio, que Mário cultivou.

O nam significa "ora pois": Ora pois, Sibila...

Nam Sibyllam... é parte dessa obra não conclusa, pequena, importante, intensa, mas inacabada (Benedito Nunes, comunicação pessoal, 2008).

"Nam Sibyllam..." faz parte do livro "O Homem e sua hora" (Faustino, 1955) e os seguintes versos constituem a primeira estrofe: "Lá vi o pó do espaço me enrolando / em

CHAVES, Lilia Silvestre. O filósofo e o poeta. Boletim do Museu Paraense Emílio Goeldi. Ciências Humanas, v. 6, n. 2, p. 377-393, maio-ago. 2011.

Autor para correspondência: Lilia Silvestre Chaves. Universidade Federal do Pará. Centro de Letras e Artes. Departamento de Língua e Literatura Estrangeiras. Rua Augusto Corrêa, 01. Cidade Universitária. Guamá. Belém, PA, Brasil. CEP 66075-110 (liliasilvestre@gmail.com). Recebido em 25/07/2011

Aprovado em 19/08/2011

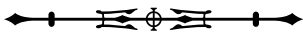


turbilhões de peixes e presságios - Pois na orla do mundo as delatantes / sombras marinhas, vagas, me apontavam". Benedito Nunes nos ofereceu duas horas de desvelamento do poema, mostrando estampas das Sibilas pintadas no teto da capela Sistina, gravações de canções gregas e citações de versos de outros poetas. Em seu semblante, via-se que experimentava enorme prazer na leitura e na interpretação que dividia com o público presente, provando a sua teoria de que a interpretação de um texto poético exige uma prévia autocompreensão do intérprete.

Em um dos primeiros textos em que discorreu sobre a exegese de textos literários - "O trabalho da interpretação e a figura do intérprete na literatura" -, Benedito Nunes inicia retomando a pergunta com a qual Alfredo Bosi termina o seu ensaio "A interpretação da obra literária" (ambos publicados em 1986, no segundo volume de "Literatura brasileira: ensaios, criação, interpretação e leitura do texto literário", que reúne os textos das conferências realizadas na 2. ${ }^{a}$ Bienal Nestlé de Literatura Brasileira): "por que interpretar?". É preciso interpretar, responde Nunes, porque não há signos transparentes, as palavras são opacas, ou seja, não há uma relação direta entre palavra e coisa: "se a grafia nos mostrasse o significado, como o desenho o seu modelo", não seria necessário o trabalho da interpretação. Há de haver uma espécie de diálogo entre o intérprete e o texto, "uma dialética da questão e da resposta: interpelação mútua de um pelo outro, o intérprete questionando o texto e sendo por este questionado" (Nunes, 1986a, p. 73). É interagindo com o leitor que o texto, afinal, se torna plenamente obra:

Interpretar uma obra é, portanto, desdobrar o mundo a que ela se refere, mas na modalidade como se da ficção, que também se abre, através da linguagem, para as estruturas gerais da existência humana, tais como a tonalidade afetiva ou disposição anímica, a apropriação projetiva do mundo e a intersubjetividade (Nunes, 1986a, p. 73).

Em "Leitura de poesia", livro organizado por Alfredo Bosi, Benedito Nunes (1996) como que ilustra a sua teoria sobre interpretação, analisando "O 'fragmento' da Juventude", também poema de Mário Faustino.

A oportunidade de ouvir Benedito Nunes 'examinar' um poema foi uma dádiva. Não foram muitas as vezes em que ele mais concretamente interpretou um poema como um todo. Grande parte dos seus ensaios críticos dedicam-se geralmente a comentar uma obra - como a do próprio Mário Faustino, a de Clarice Lispector, João Cabral de Melo Neto ou Fernando Pessoa, entre muitas outras, ou ainda o vasto romance de Guimarães Rosa, poético, porém não um poema.

Foram três anos consecutivos, no Simpósio Olhares sobre o Poético, que Benedito Nunes, no auditório que tem o nome do professor Francisco Paulo Mendes - mentor intelectual de sua geração -, dedicou-se a mostrar o resultado "desse trabalho tenaz que se chama interpretação": "Nam sybilam...", em 2008; "Gaivota, vais e voltas", em 2009, ambos de Mário Faustino; e, em 2010, "Travessia", de Max Martins. Todos, poetas e professor, foram grandes amigos de Benedito Nunes.

\section{O TEMPO DO SOBREVIVER MEDE O TEMPO DA AMIZADE}

A amizade entre Mário e Benedito jamais arrefeceu e iluminou a existência do que sobreviveu ao outro, mesmo para além da morte, pela lembrança e fidelidade a um nome. Passaram-se quinze anos, desde que se conheceram em 1947, até a morte de Mário Faustino, em 1962, e grande parte desse tempo os dois viveram na ausência, comunicando-se e comungando por escrito, Benedito Nunes em Belém e Mário Faustino, durante suas viagens, e depois quando passou a morar no Rio de Janeiro ou em Nova York. Se a distância separa a convivência, as cartas mantêm o diálogo (do qual geralmente só ouvimos uma das vozes, a de Mário Faustino). Talvez pudéssemos comparar esse sentimento da amizade na presença ou na ausência com aquele que uniu Montaigne a seu amigo (durante seis anos, dos quais dois sem se verem), ou Fernando Pessoa a Mário de Sá-Carneiro (três anos e meio), amizade igualmente

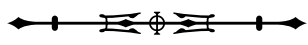


profunda e total, celebrada também além-túmulo, com fidelidade e alegria: "Nós já nos procurávamos antes de nos termos visto", escreveu Montaigne (1969a, p. 230-242), dez anos após a morte de La Boétie. "Hoje, falho de ti, sou dois a sós”, dirigiu-se Fernando Pessoa (1969, p. 583) a Mário de Sá-Carneiro, dezoito anos depois da morte do amigo. Não conhecemos o tom das cartas de Benedito a Mário Faustino, que não as guardava, e os escritos que celebraram a morte do amigo são todos de crítica literária, difundindo a obra do poeta-crítico, analisando-a, louvando-a. Mário, o que se foi, começava suas cartas (todas arquivadas por Benedito Nunes), chamando-o de "meu irmão", "irmão caríssimo", "meu amigo" e de "meu Outro e meu Eu mesmo". Benedito, nos mais recentes textos de crítica literária ou, simplesmente, de memória, refere-se a ele com ternura: "Meu amigo Mário".

"Jamais conheci quem, como Mário Faustino, me tivesse transmitido a impressão de alguém que porejasse vida, e que sobre a vida de quantos com ele privassem exercesse um efeito estimulante e propiciador, análogo ao que a química denomina catálise" (Nunes, 1986b, p. 41). "Não sei se era infeccioso", brinca en passant Benedito Nunes, "mas ele contaminava pela sua própria irradiação" (comunicação pessoal, 2002).

Crítico literário e filósofo, Benedito Nunes dedicou uma parte de sua vida a divulgar a obra daquele que foi um de seus mais fraternais amigos, de geração, de pensamento, de formação e de vivência, o poeta Mário Faustino. Confidente, colaborador e correspondente, com alguns intervalos de silêncio, uma carta retomava o diálogo: "Finalmente, depois de tanto tempo, chegam-me tuas palavras e eis que nosso velho diálogo, que tanto contribuiu para minha formação, pode recomeçar" (New York, 1960)1.

Em sua conferência para o evento críticocomemorativo dos 30 anos da Semana Nacional de Poesia de Vanguarda (em Belo Horizonte), Benedito Nunes disse que acreditava ter sido convidado para o evento mais pela amizade com Affonso Ávila, da "Tendência", e com Haroldo de Campos, de "Noigandres" - amizade que se iniciara no Colóquio de Assis (em São Paulo) -, do que pelos seus "demasiadamente longos (...) ensaios de crítica literária e filosofia publicados no Suplemento Dominical do 'Jornal do Brasil' (SDJB), os primeiros graças à iniciativa de Mário Faustino" (Nunes, 1993a, p. 22-35, grifo nosso). Evoca, dessa maneira, o poeta-crítico (a quem chama de aliado) que, já morto em 1963, esteve, com toda certeza, in absentia durante a Semana. Assim, Benedito Nunes faz questão de lembrar o seu primeiro e mais importante mediador.

\section{A AMIZADE COMEÇA ANTES DA AMIZADE}

Antes de se conhecerem, Mário e Benedito, adolescentes, foram, por acaso, candidatos rivais de um concurso promovido pela "Folha do Norte" - em Belém do Pará-, em nome do jornal "O Globo". Como ainda não havia televisão no país, "O Globo" promoveu nacionalmente, em certos jornais, o Concurso dos Embaixadores da Juventude, cujo prêmio era uma viagem ao Rio de Janeiro. O meio para a obtenção do prêmio era a votação, e os votos a preencher saíam todos os dias na "Folha do Norte", no canto direito da segunda página do jornal. Os candidatos deviam fazer a sua propaganda, e os alunos recortavam os votos para depositá-los na urna do seu colégio. "Os representantes do Ginásio Paes de Carvalho eram justamente o Mário Faustino e a Marina Matta. $O$ candidato pelo Colégio Nazaré era o Elias Salame", conta Benedito (comunicação pessoal, 2000). "O Mário perdeu com a Marina Matta. Eu e a Eva Andersen, que éramos candidatos pelo Colégio Moderno, ganhamos o concurso e fizemos a viagem num avião que saía daqui às 5 da manhã e chegava às 5 da tarde no Rio de Janeiro. Parando... pela Cruzeiro do Sul".

Foi no mês seguinte ao concurso, em novembro de 1947, que Benedito Nunes encontrou-se pela primeira

\footnotetext{
1 Os trechos das cartas de Mário Faustino a Benedito Nunes aqui citados fazem parte do acervo pessoal de Benedito Nunes. Terão como referência a cidade de procedência e a data em que foram escritas, conforme encontradas no cabeçalho de cada carta. As cartas de Mário Faustino enviadas a outras pessoas trarão, além disso, o nome do destinatário.
}

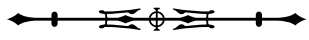


vez face a face com Mário Faustino. $\bigcirc$ encontro aconteceu na sessão (a única que houve) da Associação Brasileira de Escritores (ABDE), que estava sendo fundada naquele momento por Ruy Barata e Haroldo Maranhão - este último seu primeiro e único presidente-, que acabavam de participar, em Belo Horizonte, do II Congresso Brasileiro de Escritores e vieram com a incumbência de criar a Associação de Belém. Os intelectuais paraenses foram convocados para uma reunião, no dia 3 de novembro, para a instalação da ABDE, seção do Pará. Como autor de crônicas diárias na "Província do Pará", Mário Faustino tornara-se conhecido nos meios intelectuais e foi convidado para compor, junto com os outros escritores da cidade, a Associação da capital paraense.

Revisto mais tarde com humor ou nostalgia, o primeiro olhar entre duas pessoas que depois se tornariam grandes amigas adquire uma dimensão mítica e inscreve-se no movimento mais geral das descobertas pessoais. Os relatos de encontros e de visitas transformam-se em situações vivas e transportam o leitor para o espaço-tempo mágico da memória. Essas descrições que fixam o primeiro encontro com alguém - famoso posteriormente - transpõem para uma cena emblemática o momento inesquecível do 'quando eu o vi pela primeira vez'. Tudo é olhar nesse face a face com a memória. A lembrança parece tão presente como se a cena tivesse acontecido ontem e quem vive o momento poderia, certamente, de memória, desenhar o quadro: "Estávamos na enorme sala da antiga sede social da Assembleia Paraense, defronte da Praça da República, então Largo da Pólvora. Apresentaram-nos, então, a um rapaz que nós já conhecíamos de nome, porque ele escrevia na 'Província do Pará' crônicas quase diárias" (comunicação pessoal, 2000).

"Graças ao nome" - segundo a expressão de Derrida (1994, p. 324) -, "a amizade começa antes da amizade, graças ao nome a amizade sobrevive à amizade, sempre a amizade começa por se sobreviver". Segundo Benedito,

Essa apresentação informal - o clima era muito amigável - foi o início da nossa amizade e da amizade também muito grande, talvez muito profunda, que ele contraiu com o Francisco Paulo Mendes.
Todos nós, que estávamos muito vinculados ao suplemento literário da "Folha do Norte", conhecemos o Mário (comunicação pessoal, 2000).

"Todos nós conhecemos o Mário". O nós, aqui, assume alternadamente a força abrangente da primeira pessoa e o plural do grupo que volta à vida como em uma fotografia. Esse grupo, que assinava o editorial de colaboradores do Suplemento Arte-Literatura, da "Folha do Norte", era quase o mesmo que se reunia no salão do Café Central. O pacto da amizade firmou-se entre eles:

Na Belém de trezentos mil habitantes, pós-Segunda Guerra Mundial, havia, apesar do calor, clima para longas caminhadas a pé, para passeios nos velhos bondes, que seriam os últimos, ou nos novos ônibus, que então começaram a circular, e para demoradas conversas nas casas de um e de outro, que se prolongavam nos cafés, sobre os livros que líamos. De caminhada a caminhada, de leitura a leitura, tornamo-nos íntimos, fraternais amigos: visitávamo-nos mutuamente sem hora marcada (Nunes, 2000a, p. 39).

Passaram a frequentar-se. Em geral pela manhã, em sua própria casa, Mário Faustino dava aulas de inglês a Benedito Nunes - que era um ano mais velho. As aulas baseavam-se na leitura do "Sparkenbroke", de Charles Morgan, "livro da predileção do meu professor (...), que há pouco tempo atrás tentei reler e não consegui", relembra Benedito Nunes (2000a, p. 39).

Com a convivência, Mário logo se apoderou das tias que criaram Benedito Nunes - filho único que teve à sua volta as manias e os cuidados de sete tias, irmãs de sua mãe, Maria de Belém, com quem dividiam o menino e a casa. Um modelo da antiga arquitetura de Belém, a casa ainda existe na atual avenida Gentil Bittencourt, no bairro de Batista Campos, entre as ruas Serzedelo Corrêa e Presidente Pernambuco, perto do cemitério da Soledade. Com o pé direito muito alto, lustres com longas correntes, tetos desenhados, assoalho em marcheterie e móveis de época - como as cadeiras austríacas de espaldar alto -, a sala de visitas dessa casa assistiu a muitas sessões literárias, desde as reuniões da Academia dos Novos (fundada por 
Benedito e Haroldo Maranhão, Alonso Rocha e Max Martins, em 1943).

Dirigindo a habitação, e cada uma com sua característica e incumbência nos afazeres domésticos, 'as tias' viviam em uníssono, mas, como em uma pequena orquestra, todos os íntimos da casa com seus ouvidos atentos poderiam identificar perfeitamente o naipe de cada uma. De todas, Mimita - cujo nome completo era Maria Emília Viana - foi a que sempre esteve mais apegada afetiva e mesmo intelectualmente a Mário. Para elas, Mário Faustino reservava um apelido carinhoso e recomendações nas cartas que mandou ao Bené, com uma certa frequência, pela vida afora, quando não se encontrava na terra: "E as minhas queridíssimas tias?".

Mário escrevia que o melhor das cartas que o amigo lhe mandava eram as notícias das

muyto falladas aventuras da muy leal y ardorosa cavalleira andante Dona Maria da Belém, mãe do supradito Bené. Pobres cachorros, pobre, pobre Oscar, pobre Dacida, pobres aves, sem esquecer o Garibaldi (se é que ainda existe esse frango!). Está faltando em Belém uma poderosa sociedade protetora dos animais (Teresina, 15 nov. 1951).

Na sua ausência, Mário reclamava ao Bené notícias dos deliciosos cookies e "mimitilhas" (as pastilhas da Mimita), da elegante Dodó, da inesquecível Joaninha Buscapé, da doce Gugu querida, obscurecidas, talvez, nas cartas que lhe levavam as histórias da casa das Viana, pela sombra heróica e beligerante da Senhora Dona Maria de Belém, na sua importância de mãe titular. Todos os domingos, "nós íamos ao cinema Olímpia, à sessão que começava às seis e meia da tarde. Então, eu jantava antes. A Mimita, a tia mais velha (...), preparava um jantarzinho, às vezes o Mário participava do jantar, e depois nós saíamos" (comunicação pessoal, 2000).

Encontravam-se amiúde no Café Central, "uma dependência do Central Hotel, onde os garçons serviam chá, cafezinho, sorvete e salada de frutas, em mesas de tampo de mármore com moldura de madeira" (comunicação pessoal, 2002). Esse famoso Café Central assistiu ao surgimento de vários talentos literários, alguns dos quais ultrapassaram os limites da província. A maioria deles acabava escrevendo poesia, por influência de Francisco Paulo do Nascimento Mendes, crítico de literatura e de arte, ensaísta e professor de Literatura Portuguesa e de História da Arte, na Universidade do Pará. Tornou-se a figura em torno da qual os mais jovens se agrupavam, o que lhe valeu o epíteto de 'fazedor de poetas'. Todos ali, de certa maneira, espelhavam-se em Francisco Paulo Mendes, que fazia do salão do Café Central a sua própria sala de visitas. Mendes era, na verdade, um fazedor de escritores, pois também iniciou e encorajou críticos e prosadores. Haroldo Maranhão, por exemplo, enveredou pela prosa de contos e romances, e Benedito Nunes prosseguiu no rumo do texto ensaístico, dos estudos filosóficos e críticos.

\section{OS MEUS SONHOS NÃO CABEM AQUI}

Excetuando-se aqueles que circularam no jornalzinho artesanal de Haroldo Maranhão, "O Colegial", os primeiros textos de Benedito Nunes que conhecemos são os dois capítulos iniciais de um romance, "João Silvério", publicados no primeiro número do Suplemento da "Folha do Norte", em maio de 1946. "Imitação, talvez, do 'Menino de Engenho', de José Lins do Rego", comenta Benedito (Nunes, 2007, p. 1). Anos depois, em carta, Haroldo Maranhão, a propósito de uma antologia, pede a Benedito que o autorize a reeditar os dois capítulos - 0 "Menino doente" e o "Jaqueira" -, do "romancista adolescente, que (foi pena) não o levou a cabo, pois escreveu uma prosa enxuta, fluente, deliciosa, mestre do coloquial. Farei isto, enfim, para datar o texto, e ressalvar que dessas matérias não cuida mais o sr. professor: porei embaixo a data (1946)"2.

Benedito também publicava poemas curtos, já com ares modernos, como o primeiro "Fragmento" 3 :

2 Carta de Haroldo Maranhão a Benedito Nunes, Rio de Janeiro, 15 maio 1984. Acervo de Benedito Nunes.

3 Benedito Nunes, "Fragmento". Suplemento Arte-Literatura, "Folha do Norte", Belém, 13 abr. 1947. p. 1. Todos os exemplares dos Suplementos da "Folha do Norte" aqui citados fazem parte do arquivo pessoal de Benedito Nunes. A maior parte das fotocópias não traz o número das páginas.

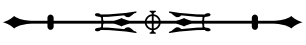


Os meus sonhos não cabem aqui

o teto é muito baixo

as janelas são estreitas

para onde voarão eles

quando houver o crescimento do homem?

Escrevia, ainda, aforismos, agrupados sob o título "Confissões do solitário" (publicados em cinco números do Suplemento, de 1946 a 1947) - que misturavam conceitos filosóficos e imagens poéticas, sob o foco de uma reflexão cética, certamente agnóstica, sobre problemas religiosos, morais e estéticos -, nos quais a transição entre a poesia e a filosofia vai se revelando por intermédio de pensamentos sobre música e sobre religião. Justamente a religião, muito presente na infância e juventude de Benedito Nunes, criado por sua mãe e tantas tias muito católicas: "Entendi, finalmente, o nexo religioso compartilhando da trama tecida pela imaginação, nativa à Literatura e não estranha à Filosofia" (Nunes, 2005, p. 289). Depois, além dos ensaios "Ação e poesia" I e II (10 e 8 de junho de 1947, respectivamente), "O cotidiano e a morte em Ivan Ilitch" (22 jan. 1950) e "Considerações sobre a Peste" (14 jan. 1951), o Suplemento da "Folha", naqueles anos de 1940 e 1950, trouxe o primeiro comentário crítico de poesia, publicado por Benedito Nunes (do qual falaremos adiante).

Muitos anos depois, já com livros publicados de crítica e estudos filosóficos, ele se definiu assim: "Não sou nem poeta nem ficcionista (...), escrevo, de preferência, ensaios literários e filosóficos, quando não comentários a livros publicados, especialmente de poesia" (Nunes, 2007, p. 1).

Por convicção própria, Benedito Nunes, de acordo com os filósofos românticos alemães e, mais tarde, com Heidegger, sempre aproximou a filosofia da poesia:

(...) nas resenhas literárias dava sempre realce a um quinhão de Filosofia. E nas filosóficas quase sempre não deixava de ressaltar uma parcela do literário ou do especificamente poético. Focalizei essas relações entrecruzadas no ensaio "Filosofia e Poesia - uma transa": transa, transação, entrelaçamento e não incorporação (Nunes, 2007, p. 3).
Benedito Nunes costumava chamar Mário Faustino de "Poeta da poesia". Louvava, assim, a obra poética do amigo, pois, tanto para o filósofo quanto para o poeta, "a poesia, na fase moderna do pensamento, passa a buscar-se a si mesma, guiada por uma exigência de conhecimento. $\mathrm{Na}$ busca de si mesma, demanda a sua própria essência e tornase, frequentemente, Poesia da poesia" (Nunes, 2007, p. 4). Poderíamos, então, chamá-lo de 'Filósofo da poesia'.

\section{OUVI A VOZ DO ANJO QUE ACORDOU: SOU POETA}

Sem dúvida alguma, foi Francisco Paulo Mendes o primeiro a influenciar Mário Faustino, pelo seu natural entusiasmo de leitor de poesia e pela convivência que passaram a ter, iniciada nas rodas noturnas do Café Central. Para Mendes, "a literatura era poesia e a poesia, maneira de sentir e de pensar, como descobrimento da vida na linguagem, tornada verbo, repetia, de outra forma, o mistério da encarnação divina, que ele, católico, reconheceu e venerou", escreveu Benedito Nunes (2001a, p. 37). Acreditava na encarnação do verbo poético, de inspiração rilkeana, ilustrada pelo verso "cantar é ser", que acabou por se tornar uma espécie de lema. O primeiro poema de Mário foi dedicado a "F. Paulo Mendes, amigo", que também foi o seu primeiro crítico. O que converteu Mário Faustino em poeta? De onde o domínio técnico do ofício de poeta, logo de início tão maduro? Repetindo a expressão de Gide, a influência nada cria, apenas desperta. $\bigcirc$ fato é que esse encontro levou Mário Faustino ao início do exercício da poesia e provocou, com o passar do tempo, o seu engajamento total na criação poética, que perdurou até o fim da sua vida.

A "primeira notícia sobre a poesia de Mário Faustino", em 1948, publicada na "Folha do Norte", foi assinada, portanto, por F. Paulo Mendes. O crítico situa Mário, de 17 anos, como um dos poetas de mais força entre os que haviam aparecido ultimamente no Brasil. "Todo poeta novo é um novo profeta: anuncia uma nova idade. Ee na palavra dele que nós depositamos a nossa esperança" (Mendes, 1948, p. 1). Os primeiros textos de Mário são a efusão de 
uma alma sensível e contemplativa que descobre um mundo intermediário entre a vida e o sonho: "Donde esta paz o sono o sonho a sombra? / Apenas leves dedos sobre os olhos / somente a mão do anjo sobre o ombro" ("1. ' motivo do anjo"). O leitmotiv da rosa e o do anjo exalam o tom de Rilke, tanto na efusividade do início quanto na ânsia de mudar, quando a fonte se exaure, o que, para Mário, só acontecerá alguns anos depois, em 1952, quando viajou para estudar na Califórnia, em sua primeira viagem para a América do Norte, momento em que rompeu a amizade com Francisco Paulo Mendes e em que sua poética se transformou:

(...) produto de um severo adestramento na ascese, na depuração de sentimentos e palavras, a egolatria [dos primeiros poemas] cedendo passo a uma admirativa contemplação do mundo, como em seu poema americano, "No trem, pelo deserto", escrito em sua permanência na Califórnia (...) com uma textura que antecipa a argamassa rítmico-metafórica de "O Homem e sua hora" e a soltura prosaica dos poemas experimentais (Nunes, 2000a, p. 40).

Depois de um ano nos Estados Unidos e outro ano viajando pela Europa, Mário regressou à casa paterna, ao espinhento caminho da faculdade (que logo depois abandonou, no quarto ano, por perda de interesse), do jornal, do emprego público que lhe deram de volta.

Mário e Benedito trabalharam no mesmo setor da Superintendência do Plano de Valorização Econômica da Amazônia (SPVEA), na gestão do historiador Arthur Cezar Ferreira Reis, conforme se lê em "Dois ensaios e duas lembranças" (Nunes, 2000a, p. 39): "Deu-se que nós dois éramos, ao iniciar-se a década de 50 , funcionários de diferente escalão, eu Chefe de Setor e ele redator [da seção de divulgação], hierarquicamente a mim subordinado", conta Benedito Nunes, e comenta o processo de criação de Mário Faustino: "Pressionado pela lei capital de sua vida, Mário redigia celeremente o material noticioso do dia que lhe passava no começo do expediente matinal. 'Tudo pronto, não me chateies mais', dizia ele" (Nunes, 2000a, p. 40). la para sua casa, que ficava defronte da sede do setor, na vila Bolonha, dizendo ter que acabar um poema. Do outro lado da rua, acenava da janela do quarto e sentava-se para escrever.

Outras lições de ritmo e de imagens, que incorporava às suas poéticas, Mário Faustino aprendia nas traduções que fazia para o inglês de poemas de "Claro enigma", recém-lançado por Carlos Drummond de Andrade. Essas traduções são comentadas em um artigo de Benedito Nunes, intitulado "Drummond, poeta anglo-francês", publicado, segundo lembra o autor, sem especificar a data, há muito tempo no Suplemento do "Estado de S. Paulo" e há pouco tempo no livro "Clave do poético":

\begin{abstract}
Quando, no início da década de 50, ainda frequentava a Faculdade de Direito, em Belém, o poeta Mário Faustino, que já se distinguia como tradutor de poesia, fez um curioso exercício de versão, passando para o inglês, língua que lhe era muito familiar, o poema 'Estâncias', de Carlos Drummond de Andrade. Lido em voz alta pelo próprio Mário, naquele "puro sotaque oxfordiano" de que ele se gabava mais por pilhéria que por vaidade, o texto de Drummond colava tão perfeitamente à língua inglesa, em ritmo, significação e imagem, que parecia ter sido originariamente escrito nesse idioma. Interpretando a sua proeza de tradutor, o poeta de "O Homem e sua hora" atribuía o êxito desse mimetismo linguístico à alta eficácia da linguagem de Drummond. Era, segundo dizia, uma prova experimental, prática, de laboratório, da universalidade dessa linguagem cujos valores poderiam subsistir em qualquer outra língua (Nunes, 2009, p. 233).
\end{abstract}

\section{O BENÉ-JOÃO AFONSO, CRÍTICO DE POESIA}

Benedito Nunes conservou todas as cartas que Mário Faustino lhe escreveu, cartas em que a vida é transformada em texto, original, autobiográfico, fragmentado, secreto, talvez o mais vivo documento sobre a vida e a arte do poeta. E que permite ao filósofo-crítico, como interlocutor privilegiado, uma compreensão maior de Mário. Essas cartas retomam assuntos comuns entre ele e Bené, referem-se a pessoas e a um mundo compartilhado e, apesar de ouvirmos somente a voz do poeta, é possível reconstituir essas falas perdidas do amigo entre as linhas escritas. Mário Faustino mostra-se como palavra íntima na

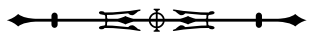


primeira carta que está colecionada no arquivo, datada de 1950. Por alguma coincidência com a origem do autor, foi escrita em Teresina.

A primeira vez que Benedito Nunes fez um comentário crítico dos poemas de Mário Faustino foi nesse início de 1951, e só nos é possível saber do desdobramento dessa crítica por meio das cartas. Depois de tanto tempo - quase cinquenta anos passados -, Benedito Nunes lembra-se perfeitamente da reportagem e do artigo crítico que provocou, sem querer, o primeiro desentendimento entre eles (talvez o único). "Foi tudo uma ideia do Ruy Barata", contou, divertido. Quando, no final de 1950, Haroldo Maranhão, responsável pelo Suplemento da "Folha do Norte", viajou de férias para Fortaleza, deixou dois números prontos para serem editados e nomeou Ruy Barata para substituí-lo. A reportagem, prevista para 24 de dezembro de 1950, era uma antologia de dez poetas paraenses - todos pertencentes a essa nova geração de intelectuais do Café Central -, da qual, entre outros, o próprio Haroldo, Benedito, Mário, Max Martins e Ruy Barata faziam parte. Ruy Barata, brincalhão, combinou com Bené que este escreveria um artigo crítico sobre a antologia e assinaria com um pseudônimo, como se fosse um crítico de fora comentando a poesia da terra. E assim foi feito. Uma semana depois, o Suplemento Arte-Literatura de 31 de dezembro de 1950 publicou uma curiosa carta de um tal Sr. João Afonso ao redator do jornal, dizendo-se crítico literário de passagem pela cidade e que, tendo lido a antologia do domingo anterior, tomava a liberdade de mandar para o jornal algumas observações que a leitura Ihe sugerira. $\bigcirc$ artigo provocou indignação entre os poetas criticados, indo atingir o diretor do Suplemento (um dos poetas), Haroldo Maranhão, que, concluindo que o artigo era de Mendes, escreveu uma resposta (que foi publicada três domingos mais tarde), combatendo a crítica mordaz do tal João Afonso.

A antologia ocupava as quatro páginas do Suplemento, com fotos dos poetas, notas biográficas e os poemas. João Afonso inicia seus comentários pelos poemas do sr. Floriano Jayme, sem nenhuma condescendência: "Nunca a Esfinge formulou perguntas que fossem mais difíceis do que os poemas do sr. Floriano Jayme". O crítico transita de um poeta para outro, interligando-os por algum traço de estilo poético que os une ou distingue. De Mário Faustino, os poemas eram os mesmos do início de 1948, os do "Motivo da rosa", os dois "Poemas do anjo" e "Elegia". Nas palavras do crítico: "O sr. Mário Faustino parece ter encontrado o seu mundo particular (...). É, segundo os dados biográficos, um rapaz de apenas vinte anos que, para surpresa nossa, pode dispor de uma técnica que os bons poetas só usam aos quarenta". Foi por essa razão que "conseguiu revalorizar, imprimindo um cunho pessoalíssimo de tratamento, dois temas que foram a consagração de muitos poetas notáveis e a tábua de salvação de um sem número de medíocres: o Anjo e a Rosa". E continua, sem ter consciência de repetir algumas das ideias que Paulo Mendes escrevera dois anos antes. Nunes esboça com segurança - mesmo se tratando de uma brincadeira - sua leitura dos primeiros passos de um poeta, de cuja obra, mais tarde, seria o maior e mais fiel divulgador.

Daí dizermos que o seu universo poético é vacilante. Vacila sob o peso duma grande beleza ainda não inteiramente possuída. Uma beleza insincera, que ele captou por meio de sua técnica, de sua habilidade para o verso e que não encontra uma base espiritual - enfim, uma beleza sem mundo, que tem apenas a vida que lhe dá o poder mágico da palavra (Nunes, 1950, p. 1-3).

Depois, o crítico ataca a si mesmo: "Os achados [poéticos] puramente casuais não representam uma conquista definitiva na vida do poeta. É o que nos sugere a poesia do sr. Benedito Nunes. Aqui e ali, um e outro achado, que ele não soube aproveitar, mostrando-se quase que inteiramente desprovido do manejo da técnica do verso". A Max Martins coube uma alusão à foto escolhida: "Numa das fotografias aparece o sr. Max Martins acendendo um cigarro. Eis um motivo que ele não deixaria de aproveitar. A sua poesia tem o cotidiano como matéria prima". Então, comenta o "profundo sentimento de viver que lateja [nos] poemas [de Max]” (Nunes, 1950, p. 1-3). 
Esse episódio revela a importância do Suplemento - local, mas de amplitude nacional - naquele pequeno mundo da cidade provinciana, em que os leitores se constituíam, na sua maioria, dos próprios colaboradores do jornal, compostos pelos dois grupos que atuavam na vida intelectual da terra: as gerações velha (do final dos anos 1930) e nova (a turma do Café Central), que se entrechocavam, uma desdenhando a outra. Como um campo neutro, o "Suplemento Literário da 'Folha' traduziria, durante cinco anos, o espírito comum, afinado pela leitura dos mesmos poetas, ficcionistas e filósofos e pela admiração votada aos mesmos artistas" (Nunes, 2001b, p. 16).

\section{MÁRIO FAUSTINO, POETA-CRÍTICO}

Talvez Mário Faustino seja mais conhecido como poeta: o poeta de "O homem e sua hora", que, agindo, criando e existindo com o poema, escreveu sua morte e viveu sua própria escrita, deixando seu rastro como um "bólide trespassando chão-essência / peito-presença" ("Cavossonante escudo nosso"). Hoje, no panorama da literatura brasileira, a maioria dos autores que citam o poeta piauiense o situa ao lado daqueles que tomaram uma direção diversa da chamada geração de 1945. No prefácio de "Poesia de Mário Faustino", Benedito Nunes (1966b, p. 16-24) considera a "arte da composição utilizada por Mário Faustino em 'O Homem e sua hora' liberta do dualismo matéria/forma" que preocupou a geração de 1945. Mas, a sua experiência criadora de poeta estendeuse à experiência reflexiva do crítico e teve a oportunidade de produzir um amplo trabalho de celebração, de revisão e de comentário da poesia contemporânea.

Segundo Mário Faustino pensava - pensamento que é fundamental para compreendermos o rumo de sua experiência de poeta - o artista, em nossa época, está fadado a ligar a criação à investigação, o fazer poesia ao trabalho de crítica. Arauto de coisas novas, precisa o poeta manter-se em permanente contato com a tradição viva, de onde o novo se alimenta. A poesia não pode progredir sem que toda essa tradição seja injetada na sensibilidade moderna. É pela reatualização de passadas vivências, pela descoberta do processo evolutivo das formas poéticas e, por fim, pela aprendizagem das técnicas que constituem os dados essenciais de toda uma cultura literária que nos foi legada, que a renovaçõo da poesia se processa. (...) Por todas essas razões, Mário Faustino, que jamais perdeu de vista as ligações da poesia com a totalidade da cultura, duplicou o seu labor pessoal de poeta, a caminho de sua obra máxima, com esta atividade de crítico, de didata da poesia, que empregou na elaboração da página semanal do Suplemento Literário do Jornal do Brasil (Nunes, 1966b, p. 7).

Em 1977, a editora Perspectiva publicou grande parte dos ensaios críticos de Mário Faustino, em livro organizado por Benedito Nunes. Para a introdução, Benedito escolheu como epígrafe uma frase de Baudelaire, escrita na ocasião do Salão parisiense de 1846, em que o poeta e crítico francês lembra que a atividade crítica é indissociável da experiência humana: "la critique doit accomplir son devoir avec passion; car pour être critique on n'en est pas moins homme"4. A epígrafe, além de remeter ao próprio métier de Benedito Nunes, antecipa a ideia de que a produção escrita de Mário Faustino e sua existência são indissociáveis, e justifica o título da página que o poeta-crítico idealizou e praticou, dedicando-se a ela com a paixão de seu temperamento.

Consideradas do ponto de vista do contexto histórico-social, tanto a sua obra poética quanto a sua atuação enquanto jornalista e crítico (propondo novos modelos crítico-criativos e apoiando os movimentos de vanguarda) representaram marcos para a poesia e para crítica no Brasil. Mário "guiou os juízos dessa crítica [em] uma concepção do poema como objeto estético e documento humano" (Nunes, 1993b, p. 13). Em "Crítica literária no Brasil, ontem e hoje", Benedito Nunes (2000b, p. 51-79), comentando a participação dos poetas-críticos no debate da crítica sobre a linguagem poética, une o nome de Mário Faustino, que defende a harmonia entre o novo e

\footnotetext{
4 "A crítica deve cumprir seu dever com paixão; pois, por ser crítico, não se é menos homem". Tradução da autora.
}

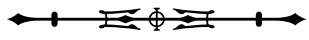


o tradicional, aos de Décio Pignatari, Augusto de Campos, Haroldo de Campos, Ferreira Gullar e Mário Chamie.

\section{QUEM DIVULGA QUEM?}

No ano em que Juscelino Kubitscheck foi eleito presidente da República (1955), Mário Faustino editou o seu primeiro livro de poesia, "O Homem e sua hora". Do Rio de Janeiro, ele escreve a Benedito Nunes para dar notícias: "saudades, saudades tuas, de Belém, do Setor mesmo, de tudo! Cheguei à conclusão de que não posso viver senão aí. Terão que me expulsar, se não me quiserem mais... E vós, tende-vos lembrado do poeta ausente?" (Rio de Janeiro, 18 mar. 1955). O seu livro já se encontrava nas mãos do editor, metade pago, por contrato, e deveria estar pronto em junho ou julho seguinte. Preocupado em divulgá-lo, Mário Faustino pretendia entrar em contato com Álvaro Lins, e deixara uma cópia com Carlos Drummond de Andrade. O poeta de "Claro Enigma" tinha elogiado: "Se ele escrever num jornal qualquer a metade do que disse de viva voz a mim e aos outros, estou de glória feita" (Rio de Janeiro, 7 abr. 1955). Quanto ao impacto do livro em Belém, recomendava a Benedito Nunes que fosse preparando os "rodapés" a respeito, com o material que já possuía: "A glória em Belém compete ao teu ensaio, que roo as unhas por ver publicado e ler. Não é vaidade: mas, se publico, o livro precisa ser lido e para tanto é necessário chamar a atenção do público" (Rio de Janeiro, 7 abr. 1955).

Ao invés de julho, com previra, o livro (único publicado em vida) só saiu em novembro de 1955. Muitas notas em jornais e revistas do Brasil fazem menção à obra. Há que se destacar, em 1956, na revista "Diálogo", um artigo de Mário Chamie (1956, p. 121), que vê nos versos do poeta estreante "um novo padrão de sensibilidade estética”. ○ 'Bené', como sempre, atendeu ao pedido com uma longa análise crítica do livro de estreia do amigo. Esse ensaio, publicado em "A Província do Pará" e também no "Jornal do Brasil", no Rio de Janeiro, revelou o crítico paraense para os leitores dessas cidades.
Benedito Nunes escrevia pela segunda vez sobre a poesia de Mário Faustino, que surpreendia pela "maestria do poeta, reduzido à condição essencial de artífice" (Nunes, 1956a, p. 10). Esse gesto de promover a obra do poeta piauiense repetir-se-á várias vezes no futuro: em cada publicação póstuma, Benedito será o organizador, apresentando, analisando, difundindo a poesia de Mário Faustino. Benedito Nunes tornou-se o crítico por excelência da obra do amigo.

Mas, antes disso - confessa ternamente o próprio Benedito -, o papel de divulgador seria assumido por Mário Faustino. No ano seguinte à publicação do seu livro, Faustino transfere-se definitivamente para o Rio de Janeiro. Começa, então, a divulgar os ensaios do crítico paraense. Em carta de agosto de 1956, Mário faz a primeira referência ao Suplemento, cuja página literária viria a assinar logo depois: "Junto a esta estou enviando o Suplemento do 'Jornal do Brasil', atualmente o melhor daqui, o mais sério e mais conceituado, que publicou, em dois números, infelizmente com alguns erros de revisão (não a fiz), o teu ensaio" (Rio de Janeiro, 15 ago. 1956). Assim foi apresentado o ensaio de Benedito Nunes:

\begin{abstract}
A Editora "Livros de Portugal" lançou, em novembro do ano passado, um livro de poemas que mereceu, desde logo, as atenções dos 'reviews', mas que, pelo menos até agora, não foi submetido à análise de uma crítica mais profunda (...). Essa lacuna é agora preenchida pelo ensaio que ocupa esta página, trabalho em que o Sr. Benedito Nunes - jovem crítico literário e professor de Filosofia na Faculdade de Belém do Pará - estabelece em suas verdadeiras proporções a contribuição daquele poeta ao processo e desenvolvimento dos meios expressionais ora em curso na poesia de nossa língua (Suplemento Dominical do "Jornal do Brasil", Livro de Ensaio, 1956, p. 10).
\end{abstract}

O estudo sobre "O Homem e sua hora" apresentou Benedito Nunes ao "Jornal do Brasil" e aos leitores do Rio de Janeiro. Ao publicar o texto do amigo sobre sua poesia, o poeta começou a divulgação dos escritos do crítico paraense, que, segundo ele, ao insistir em ficar

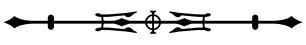


morando em Belém, corria o risco de permanecer para sempre desconhecido no resto do Brasil, pois ninguém podia passar, intelectualmente, sem um grande centro, uma biblioteca e muita aventura:

que tu escreves cabe magnificamente na metrópole. (...) Não importando o que digas catatimicamente em tua defesa, continuo a temer por ti. Ah, meu caro, só os deuses poderão salvar-te. Se quiseres salvar-te com tuas próprias mãos, aproveita a primeira oportunidade e sai daí. (...) Não te julgues mais forte do que os outros, frágil criaturinha. Não fossem as minhas viagens, eu não teria feito nada até agora: asseguro-te. Não conseguirás ser o primeiro (Rio de Janeiro, 4 set. 1956).

Inicia-se, então, a insistência junto a Benedito Nunes para que colaborasse no Suplemento, primeiro por parte do diretor do caderno, depois por iniciativa do próprio Mário Faustino, que já começava a traçar, sem sentir, os planos de sua nova tarefa: a de mediar a literatura.

Sugiro que escrevas sempre para o Suplemento. Manda-me e receberei o dinheiro que pagarem e te remeterei. Manda logo o ensaio sobre Fernando Pessoa (...). E vê se manténs um rodapé de estudos de filosofia: notas, comentários sobre livros, pequenos ensaios, estudos mais longos (que poderias publicar em capítulos) etc... Mas manda mesmo (Rio de Janeiro, 15 ago. 1956).

A página "Poesia-Experiência" ainda não havia sido criada. Os ensaios de Benedito Nunes saíram em outras páginas do Suplemento, lidos e revistos por Mário, que reclama da ortografia, mas elogia o conteúdo:

Li e revi - isto é, fiz a revisão do original, corrigindo a péssima ortografia - o ensaio do F. Pessoa. Está ótimo, vai causar grande sucesso. A primeira parte deve sair domingo próximo, no Jornal do Brasil. Este, a partir deste ensaio (o outro, sobre myself, ficará mesmo grátis), te pagará quatrocentos cruzeiros por colaboração, não importando se quilométrica ou centimétrica (Rio de Janeiro, 4 set. 1956).

A partir daí, o crítico paraense não deixou de mandar seus escritos para o Rio e, nas cartas que recebia de Mário Faustino, havia sempre referência ao recebimento e ao pagamento dos artigos publicados, em uma espécie de prestação de contas eterna.

Benedito e Maria Sylvia Nunes costumavam passar férias no Rio de Janeiro, mas para Mário não era suficiente. Em grande atividade, escrevia reclamando a vinda dos amigos para respirar novos ares:

(...) afinal, não se pode abandonar de todo todos esses jovens belenenses que precisam da assistência de vocês três [Maria Sylvia, Benedito Nunes e Angelita Silva]. Entretanto, espero que vocês continuem a semear por aí, porém sem se esterilizarem ao mesmo tempo. Os ares da capital podem dar um jeito nisso: venham (...) respirar um pouco (Rio de Janeiro, 18 set. 1956).

E dizia: "até o Rio serve: basta escolher com quem se anda, evitar a burocracia e a falsa aventura literária e tudo corre bem aqui" (Rio de Janeiro, 15 ago. 1956). Essa insistência com os Nunes, para que se mudassem para o Rio, adquire nuances diferentes com o passar do tempo. Em 1957, lamentava: "estás completamente alheio ao movimento daqui, que é intensíssimo, cada vez mais, e todo centralizado no 'Jornal do Brasil', que atualmente, sem sombra de dúvida, comanda a vida literária do país" (Rio de Janeiro, 1957). Pedia ajuda e material como se fossem pão e água: "Estou coligindo material à beça" (Rio de Janeiro, 25 out. 1956). A cada carta repetiam-se pedidos de colaborações, de livros, de textos críticos, de poemas: "o Suplemento do Reinaldo é devorador". Em 1958, mudou ligeiramente de ideia quanto à mudança de Benedito Nunes para o Rio: "Devido ao ambiente universitário que ora nasce em Belém, inclino-me a pensar que talvez não seja tão absurda a tua permanência aí" (Rio de Janeiro, 19 mar. 1958). Em dezembro, voltou à carga: "Quando vens? ISEB (Instituto Superior de Estudos Brasileiros), Fundação, Universidades, tudo te espera para um ano intenso de trabalho, quem sabe para toda uma vida de trabalho. Se eu estiver aqui ano que vem trabalharemos muito e brincaremos muito; sabes, há o automóvel... os arredores do Rio são a coisa mais bela do mundo e ainda não os conheces bem" (Rio de 
Janeiro, dez. 1958). Mas, em 1959, quando Mário escreve dizendo que não valia mais a pena ler o Suplemento "só tem neo-concretismo (imagine!) de cabo a rabo. Uma gagazice" (Rio de Janeiro, 3 jun. 1959) -, sua página "Poesia-Experiência" deixara de ser publicada. Em fevereiro desse ano, Mário Faustino entrou para o corpo redacional do "Jornal do Brasil", depois passou a ocupar o cargo de confiança de 'Coordenador de Opinião'. No fim do ano, licenciou-se do cargo, até junho de 1962.

Benedito Nunes nunca abandonou a sua província. Ele pertence, nas palavras de Antonio Candido (2009, p. 106),

a um tipo muito característico de intelectual, o que não renuncia à sua província. Nós temos o caso dele no Pará; o caso do Gilberto Freyre, em Pernambuco; do Érico Veríssimo, no Rio Grande do Sul; e do Emílio Moura, em Belo Horizonte. Respeito muito esses intelectuais, que resistem ao magnetismo das grandes metrópoles.

Viajava bastante e depois voltava para sua casa, na Travessa da Estrella, para seus livros, seu jardim. Ainda em 1959, no Festival de Teatro dos Estudantes, de Paschoal Carlos Magno, Maria Sylvia Nunes, com a peça "Édipo Rei”, ganhou o Prêmio França de Melhor Direção, e em dezembro o casal Nunes embarca, no Rio, rumo à Europa, pela primeira vez.

Em seus ensaios, Benedito retraça o caminho poético de Mário Faustino com tanta força e propriedade, que é quase impossível encontrar ensaios de outros críticos, sobre a obra poética do poeta piauiense, que não repitam trechos ou expressões de suas análises. Percorrendo a obra de Mário, poemas inéditos, projetos abandonados (recuperados nas obras publicadas postumamente, organizadas por Benedito Nunes, e no início também por Haroldo Maranhão) e lendo suas cartas, onde o poeta ora os comentava, ora procurava expressar o sentimento existencial que o possuía no momento, a leitura crítica aponta, lê, interpreta - como as Sibilas apontavam os sinais dos augúrios - temas pressagos da poesia, da morte e da vida revivida:
A morte, que tão cedo interrompeu esse projeto generoso, não frustrou a contribuição de Mário Faustino à poesia brasileira (...). O poema longo, do qual deixou-nos uns poucos fragmentos, interados à sua obra poética, completou-se paradoxalmente, como realização existencial do artista. Pois não quis o poeta que essa poesia coincidisse com o transcurso de sua vida? Era da vida terminada, em qualquer momento, que essa poesia começaria a existir; no fim de uma estava o princípio da outra. In my beginning is my end - é o que se poderá dizer como epitáfio ao poeta e como epígrafe à sua obra (Nunes, 1966a, p. 2).

\section{NO MEU FIM ESTÁ O MEU COMEÇO: A MORTE DE MÁRIO FAUSTINO}

Se a vida e a morte são extremidades opostas, através da morte o homem é conduzido à vida, como acreditava Mário Faustino. Essa ideia é compartilhada por T. S. Eliot, conforme se pode observar no verso "No meu fim está o meu começo". O antagonismo vida-morte resolve-se, em Mário Faustino, em eterno movimento de separação e de conciliação dos contrários. Segundo Benedito Nunes, que cita Heidegger, essa seria a existência autêntica, a "do ser humano que aceita a morte tão completamente que pode não só retirar-lhe o aspecto de acontecimento infausto como alcançar, através da morte, a verdadeira dimensão dos acontecimentos humanos, expungidos de equívocos e conflitos" (Nunes, 1966b, p. 9).

Pouco antes de partir para Nova York, a trabalho, em 1962, o poeta visita Belém pela última vez. Mário Faustino, que morava no Rio de Janeiro, precisou voltar ao lugar onde, mais do que em qualquer outro, ele se dizia feliz: "Minha realidade, Bené, são vocês, e Belém" (Nova York, 2 ago. 1960). Queria rever os amigos do Café Central. Visitou-os a todos. Na casa de Benedito Nunes, reviu os livros, a torre, a biblioteca com seu pequeno palco. Matou a saudade do casal que, segundo ele, seguia "se desenvolvendo paralelamente, se completando sem se anularem mutuamente, tudo bem na Estrela, ao longo da Estrela, ao pé da Estrela, em torno da Estrela, à margem da Estrela" (Nova York, 2 ago. 1960). Muito tempo depois, na memória de Benedito, Mário trazia, em si, uma gravidade

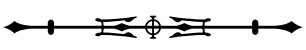


peculiar - "havia nele, nos seus gestos, nos seus atos e palavras, aquela recolhida atitude de desprendimento ou desapego, máximo sinal de uma sabedoria trágica, de quem se distanciara em relação a si mesmo, às pessoas e às coisas" (Nunes, 1986b, p. 43-44).

Mário Faustino não podia simplesmente saber que chegava ao fim. Mas havia uma espécie de convicção íntima, como uma consciência inexplicável da morte próxima. Todos com quem ele esteve comentaram que o poeta agira como se estivesse dizendo adeus. A expressão tantas vezes repetida - "Era como uma despedida" - diz respeito a alguém que não espera voltar. Os amigos, ansiosos, depois do acidente, ao buscar uma explicação para a fatalidade, acabaram por recriar o que não haviam percebido antes.

Mário Faustino, ao empreender uma volta ao passado, lança ao mundo "um pedido de silêncio / ou de suspensão da pena de estar vivo" (Fragmento "entornese o mel do tempo", 1961). O tema da ironia faz parte da visão de mundo de Mário, desde os poemas de "O Homem e sua hora", em que o tempo zomba do poeta: "O tempo na verdade tem domínio (...) E ri do que desfere verbos, dardos / De falso eterno que retornam para / Assassinar-nos num mês assassino" ("Sinto que o mês presente me assassina"). "Misto de efêmero e de eterno, o tempo é (...) a 'mímica de um bufo', que se dispersa, dispersando o homem, ora a persistente afirmação da vida, fora da qual a Eternidade não existiria" (Nunes, 1985, p. 21). Quando contou sobre a última visita de Mário Faustino, os versos de outro poeta soavam na lembrança de Benedito Nunes: "Não amei bastante sequer a mim mesmo, / contudo próximo / Salvo aquele pássaro - vinha azul e doido - / que se esfacelou na asa do avião". ○ Carlos Drummond de Andrade de "A rosa do povo", que fora a revelação do novo para aqueles novos poetas da província: "Naqueles dias, Mário Faustino e Haroldo Maranhão recitavam em voz alta, exaltados com a novidade e a beleza dos versos" (Benedito Nunes, comunicação pessoal, 2002), cujo tema coincidiria com as circunstâncias trágico-poéticas da morte de Mário.
De volta ao Rio de Janeiro, depois de fazer uma série de visitas e de tomar várias providências, Mário partiu afinal.

\begin{abstract}
A morte o esperava na fronteira entre o Brasil e um país estrangeiro, em um deserto de neve. $A$ cordilheira é um não-lugar, seu relevo, irregular, suas cores, sem nome. Sem tempo, nem espaço, o que existe é um interstício entre o passado e o futuro imediato. Sobrevoando a imensidão dos Andes, os viajantes mais avisados perdem completamente o norte, não sabem mais nem a hora nem o lugar: essas noções terrestres não têm mais sentido durante a viagem: 'A vitória pertence ao tempo que no ar / Agita um homem só, troféu tripudiado / Pela noite...'

Uma explosão na noite sobre o branco das neves nas montanhas dos Andes transfigura o contorno do horizonte, confunde o esplendor das estrelas, atinge distâncias, espalhando as chamas no negrume do céu sem luzes e os destroços de sangue e ferro, na neve - 'a lava antiga é pura cal, agora' (Chaves, 2004, p. 353).
\end{abstract}

Parodiando um verso de Drummond, de "Morte no avião", Mário Faustino desintegrou-se e transformou-se em notícia: "Jato brasileiro explode sobre o Peru: 97 mortos" (manchete do jornal "Última Hora", 28 nov. 1962). Para os mais íntimos, a notícia chegou como o pesadelo do inesperado. A família de Mário Faustino persistiu por muito tempo na ideia do enterro, saindo da casa de Benedito Nunes como ato concreto e final de despedida, mas esperou em vão pelo corpo do poeta. A sepultura de Mário cravouse na perpetuidade gratuita do ar que os Andes respiram.

De uma maneira geral, os amigos intelectuais aceitaram a ausência do corpo, a metáfora do túmulo aéreo ou nevado, digno de um poeta, sem a deterioração da morte. Ainda sob a emoção do acaso, uma revoada de textos nos jornais, a respeito de sua morte, iniciou uma projeção do seu nome no sentido de cobri-la com o mistério das profecias e das indagações, elevando o homem a herói - um Ícaro moderno: "E cai da caravana um corpo alado / E o verbo ruge em plena / Madrugada cruel de um albatroz / Zombado pelo sol" ("Mito").

Todos os artigos em homenagem ao poeta parecem repetir a litania da morte em um acidente cujos destroços 
se misturam com ar e neve. Volta para ele a vida que, por uma inversão da própria frase do poeta - "till Death doth us part" -, tornou-se, pela morte, inseparável da poesia.

Quando a morte sobreveio, Mário Faustino (...) trabalhava num longo poema, que seria a obra de sua vida, a meta de suas aspirações poéticas. Desde 1959, momento em que começou a escrever essa obra, não publicou mais um só verso, e abandonou o seu primeiro plano literário, do qual chegou a me falar em carta datada de 1956, de lançar um novo livro, cujo título, "A Reconstrução", mostra-nos que, já nessa época, decorrido apenas um ano do aparecimento de "O Homem e sua hora", tentava ele superar a sua primeira experiência criadora que um tão alto nível alcançara (Nunes, 1966a, p. 2).

Para Benedito Nunes (1985, p. 42), a poesia de Mário Faustino "traz (...) a matéria da vivência do poeta desenrolada no Tempo - com os dados imediatos de sua consciência - e às custas do próprio tempo". Se a extensão do poema (e da vida) é confundida com a sua duração, o que importa é a intensidade com que o poeta viveu esse tempo e não a quantidade de anos vividos: a extensão do poema tem que ser intensiva, mesmo que fragmentária, e comandada pela experiência vivenciada pelo poeta, que luta por "fazer da poesia um equivalente verbal da duração, do tempo real vivido" (Nunes, 1966b, p. 2), esse tempo que adquire outra medida quando se trata de uma vida vivida em palavras e, ainda, de uma vida cortada 'cedo demais', como a do poeta.

\section{MEU DEVER DE MORRER: A DESPEDIDA DE BENEDITO NUNES}

Benedito Nunes, "pequeno senhor do tempo", como o chamava outro amigo poeta, Ruy Barata, viveu vida longa - morreu com 82 anos -, apesar de todos os amigos que a ele sobreviveram sentirem a profunda impressão de que ele se foi 'cedo demais'.

Em 1998, no discurso "Quase um plano de aula", feito ao receber o título de Professor Emérito da Universidade Federal do Pará, relembra o amigo Mário: "à medida que passa o tempo, vai aumentando a nossa relação com os mortos, sem que cessem o sentimento de amizade, de respeito ou de admiração que a essas pessoas devotávamos em vida, como se dá, ainda hoje, em relação a Mário Faustino, falecido em 1962. Mário não é para mim uma mera recordação, mas a terna e afetuosa lembrança de uma irmandade de ideias e sentimentos. No final, dizendose habituado a circular entre vivos e mortos, cita o verso do poeta espanhol Jorge Guilhén, confessando não se desesperar diante do dever da idade - "mi dever de morir" - e recordando seus alunos e sua vida, no tempo que passou a ensinar e a ensinar-se.

As perdas e as mudanças vividas pelo homem são ressentidas metaforicamente como uma série de mortes e renascimentos - sugeridos nas formas verbais e no jogo de reflexo do poema concreto de Haroldo de Campos:

$$
\begin{aligned}
& \text { se } \\
& \text { nasce } \\
& \text { morre nasce } \\
& \text { morre nasce morre } \\
& \text { renasce remorre renasce } \\
& \text { remorre renasce } \\
& \text { remorre } \\
& \text { re }
\end{aligned}
$$

A série de mortes e renascimentos torna mais assustadora a chamada dialética íntima da morte: a sua presença ausente. Tanto a revelação da morte em vida (na descoberta de uma doença fatal), quanto a ameaça constante do próprio fim (provocada pela identificação profunda com os mortos amados) ou, ainda, a sensação do morrer no ato mais vital do amor carnal são sinais intermitentes da finitude do ser, que permitem aos homens perceber a morte como alguma coisa profundamente sentida, familiar e próxima. A existência pessoal - que não é uma fatalidade - tem por tarefa transformar a fatalidade da morte em liberdade, pois a aceitação da morte acaba por proceder a essa transformação.

A filosofia, como a poesia, acerca-se da morte. A morte, em suas várias faces, é a musa da filosofia (a expressão é de Schopenhauer). Organizar a experiência diante da fatalidade, para que a vida ameaçada possa 
aproximar-se da morte com voluptuosidade, habituandose a ela e tornando-a familiar até perder todo o medo do fim, é o tema do ensaio de Montaigne (1969b, p. 127), "De como filosofar é aprender a morrer". $\bigcirc$ filósofo do Renascimento cita a premissa de Cícero, de que filosofar não é outra coisa senão preparar-se para a morte, ideia originalmente expressa no "Fedon", de Platão. O estudo e a contemplação fazem com que a alma se separe do corpo, o que representa não apenas uma espécie de morte em si, como também um aprendizado para não ter medo de morrer. Aprender a morrer seria um caminho para a eternidade.

O dever de morrer foi cumprido em fevereiro de 2011. Viveu o tempo de um dia inteiro, um dia bom, podia a noite chegar. Ao contrário de Mário Faustino, para quem a morte chegou sem aviso prévio e cujo corpo e sangue dispersaram-se entre os destroços de ferro, na alva neve das montanhas, Benedito Nunes foi imerso pelo branco maculado do hospital, da incerteza e da espera, enquanto o tempo e o espaço mascaravam o destino e, entre o riso e o pensamento, a perspectiva do fim, sopro a sopro, tornava-se solene e silenciava. Acolheu-o o fogo e a terra, e o sangue fez-se seiva e flor.

\section{O MISTÉRIO DO ARQUIVO - TÚMULO QUE SE PODE ABRIR, FONTE NOVAMENTE LIBERTADA}

Segundo Platão, os amigos é que são os parentes: "Se sois amigos um do outro, é que sois um para o outro de alguma maneira aparentados por natureza" (Platão apud Derrida, 1994, p. 31). A trajetória de Mário Faustino está atada à viva memória da amizade: sobreviver entre amigos é a extrema possibilidade da amizade, "é o ato enlutado do amar" - o tempo do sobreviver mede o tempo da amizade. Antes de serem apresentados, Benedito Nunes já conhecia o nome de Mário Faustino, como autor das crônicas publicadas em "A Província do Pará", entre 1947 e 1948. Graças à amizade, Benedito Nunes, que sobreviveu ao amigo, tornou-se legatário de sua obra. Pelo acaso e pela disposição deixada no bilhete que Mário entregou à sua mãe, antes de viajar. Benedito Nunes herdou os papéis e a biblioteca de Mário Faustino.

A casa da Travessa da Estrella abriga um vasto arquivo. Dois são os que contêm o maior número de documentos, textos, manuscritos, fotos etc.: o do próprio Benedito Nunes e o de Mário Faustino. Assim como os arcontes foram os primeiros guardiões dos documentos da lei, Benedito Nunes tornou-se não somente o guardião dos papéis de (e referentes a) Mário Faustino, como também a autoridade publicamente reconhecida no que diz respeito ao espólio do poeta. Os livros de Mário encontram-se em uma estante no mezanino da Torre, cujo primeiro andar servia de escritório a Benedito Nunes. Os fragmentos da obra deixada por Mário Faustino e o nada a que seu corpo foi reduzido reuniram-se em um único corpus, articulandose metonimicamente em antigas pastas de papel pardo, na primeira gaveta de um móvel cinzento, na Biblioteca Complementar I (Bicom I), uma pequena construção anexada à casa. Os textos de Benedito Nunes também estão nesse arquivo, papéis e livros que ele sempre colecionou. O corpus, que metaforicamente abrange toda sua vida, reúne seus textos, os jornais e as revistas em que publicou, ensaios apresentados em congressos e encontros dos quais participou, enfim, os papéis guardados durante a longa vida que teve o filósofo, também vivida em palavras poéticas, filosóficas, críticas.

Comparar o arquivo com um túmulo onde jazem os papéis e a memória do poeta e do filósofo recupera a vontade do pai-irmão de Mário, de um enterro simbólico, e a delicadeza de Maria Sylvia Nunes, ao deixar Benedito sob a roseira, ali no jardim da casa da Estrella.

"Tão pouco extensa quanto foi a vida de seu autor, a poesia de Mário Faustino está marcada por uma profunda unidade em contraste com o seu perfil inquieto e mutável, aparentemente dispersivo e inacabado" (Nunes, 2000c, p. 7). Foi longa a sua vida, porém não menos inacabado, apesar de sereno, o perfil de Benedito Nunes, simples e alegre sábio, cuja obra é marcada pela originalidade, autodidatismo, seriedade e leveza. 
Na obra do poeta, ao lado do movimento e do tempo, há o diálogo com a poesia pressaga, 'mágica', 'metafísica' - a que foi esculpida pelo poeta, desde "O Homem e sua hora" até o último dos fragmentos, como um só poema, com sua meada de imagens em um "completo entrelaçamento de significados, de imagens e de sons", que permitem traçar um sistema de forças a partir das matrizes básicas, que, segundo Benedito Nunes, são a religião e o amor, este concebido como erotismo universal (o tema da religião insinua-se, apenas aparentemente, em desarmonia com o tema do sexo): "A figura do Amante adquire consistência arquetípica e, platonicamente, se entrelaça com a figura do Poeta. Verbo e amor, logos e eros" (Nunes, 1966b, p. 7).

A obra do filósofo é tecida no jogo do tempo-espaço e na dialética entre a poesia e a filosofia. Parafraseando o título de um dos artigos publicados em "Crivo de papel" (Nunes, 1998, p. 45), é possível dizer que, do primeiro ao último começo, entre os temas principais que estudou, também se encontram o amor, a paixão (termo empregado em amplo sentido) e a religião - na fusão entre sacro e profano, cantada pelos poetas que "não identificam Deus e os deuses. Apenas se medem à sua plenitude oculta" (Nunes, 1998, p. 43), como ilustram os versos de Mário Faustino, que clamam "contra o peso do mundo e a pureza dos anjos", e o de Fernando Pessoa: "Não haver deus é um deus também". Há, ainda, o estudo do ser, que, na errância do pensamento, chega ao encontro consigo mesmo, encontro previsto desde o nascimento, na angústia de refletir na liberdade e na autenticidade da morte.

Diante da rapidez com que, como um bólide, Mário Faustino atravessou a vida, podemos questionar, com Benedito Nunes, na quarta das suas "Confissões do solitário", publicadas no Suplemento da "Folha do Norte" de 25 de agosto de 1946: "Para onde vai o homem, o dono do tempo, o dono do espaço?...". Tendo sempre vivido no agônico desafio da aceitação de sua provisoriedade, o poeta já havia respondido: "Minha vida, minha poesia, há de ser, em breve, uma 'durée', uma continuidade, e ipso facto, uma eternidade" (carta para Walmir Ayala, Nova York, 1. ${ }^{\circ}$ jul. 1960). E é essa poesia, em que "palavra e coisa se tornam mutuamente reversíveis" (Nunes, 2000c, p. 7), que Mário Faustino envia aos homens como mensageira de paz: “... Parte, estátua [...] / - vai aos homens / Ensinar-lhes a mágica olvidada" ("O Homem e sua hora"). Aquela que desperta os homens, para ensinar-lhes a "impressão inicial da vida" e a procurar, em si ou nas palavras, "o inatingível de cada coisa", como diz Benedito Nunes, no seu Fragmento n. ${ }^{\circ} 3$ (citado na epígrafe deste artigo). A sagração da palavra a que se dedicou Benedito Nunes - ensinar aos homens a ver a coisa, a perceber "o fogo que as reúne" -, ele a revelou desde o seu primeiro grande ensaio sobre poesia, "O Homem e sua hora" (Nunes, 1956a, p. 10). E é nessa espécie de consciência fenomenológica e poética que o filósofo e o poeta se confundem:

Na nova linha que se prenuncia em $\bigcirc$ Homem e sua hora, o poeta é revestido de uma vaga responsabilidade histórica perante a sua época. Mais nítida, contudo, é a sua obrigação relativamente à linguagem e ao pensamento. Sem afastar-se da concepção do mundo antes delineada, o poematítulo testemunha o surgimento de uma consciência fenomenológica que, exigindo o retorno às coisas - Zu den Schen Selbst - aos homens se dirige para:

Ensinar-lhes a ver a coisa, a coisa Não o que gira em torno dela, a ela Semelho, quase igual para enganar-nos. Ensinar-lhes a ver de coisa a coisa fogo que as reúne, não o gelo Que entre as coisas navega a separá-las (Nunes, 1956b, p. 6)

\section{REFERÊNCIAS}

CANDIDO, Antonio. Benedito Nunes. Revista Brasileiros, n. 25, p. 106, 2009.

CHAMIE, Mário. O Homem e sua hora (Mário Faustino). Diálogo, p. 121-122, mar. 1956.

CHAVES, Lilia Silvestre. Mário Faustino: uma biografia. Belém: SECULT/IAP/APL, 2004.

DERRIDA, Jacques. Politiques de l'amitié. Paris: Galilée, 1994. 
FAUSTINO, Mário. Poesia-Experiência. São Paulo: Perspectiva, 1977.

FAUSTINO, Mário. O Homem e sua hora. Rio de Janeiro: Livros de Portugal, 1955.

MENDES, Francisco Paulo. O poeta e a rosa, a primeira notícia sobre a poesia de Mário Faustino. Folha do Norte, Belém, n. 761, 25 abr. 1948. Suplemento Arte-Literatura, p. 1-3.

MONTAIGNE, Michel de. De l'amitié. In: MONTAIGNE, Michel de. Essais I. Paris: Garnier-Flammarion, 1969a. p. 230-242.

MONTAIGNE, Michel de. Que philosopher, c'est apprendre à mourir. In: MONTAIGNE, Michel de. Essais I. Paris: GarnierFlammarion, 1969b. p. 127-142.

NUNES, Benedito. Drummond: poeta anglo-francês. In: NUNES, Benedito. A clave do poético. Apresentação e organização de Victor Sales Pinheiro. São Paulo: Companhia das Letras, 2009. p. 233-239.

NUNES, Benedito. Da caneta ao computador ou entre filosofia e literatura. In: Enciclopédia Itaú Cultural, literatura brasileira. 12 fev. 2007. Disponível em: <http://www.conexoesitaucultural.org.br/ wp-content/uploads/2011/03/da-caneta-ao-computador-ou-entrefilosofia-e-literatura.pdf>. Acesso em: 25 maio 2011.

NUNES, Benedito. Meu caminho na crítica. Estudos Avançados, v. 19 , n. 55, p. 289-305, set.-dez. 2005.

NUNES, Benedito. Devoção à poesia. In: NUNES, Benedito (Org.). O amigo Chico: fazedor de poetas. Belém: SECULT, 2001a. p. 37-38.

NUNES, Benedito. Francisco Paulo Mendes, para além da crítica literária. In: NUNES, Benedito (Org.). O amigo Chico: fazedor de poetas. Belém: SECULT, 2001b. p. 15-24.

NUNES, Benedito. Dois ensaios e duas lembranças. Belém: SECULT/UNAMA, 2000a.

NUNES, Benedito. Crítica literária no Brasil, ontem e hoje. In: MARTINS, Maria Helena (Org.). Rumos da crítica. São Paulo: SENAC/Itaú Cultural, 2000b. p. 51-79.

NUNES, Benedito. Apresentação. In: NUNES, Benedito (Org.). Melhores poemas de Mário Faustino. São Paulo: Global, 2000c.
NUNES, Benedito. $\bigcirc$ "fragmento" da juventude. In: BOSI, Alfredo (Org.). Leituras de poesia. São Paulo: Ática, 1996. p. 171-190.

NUNES, Benedito. Trinta anos depois. In: SANTA ROSA, Eleonora (Org.). 30 anos, Semana Nacional de Poesia de Vanguarda, 1963/93. Belo Horizonte: Prefeitura Municipal, Secretaria Municipal de Cultura, 1993a. p. 22-35.

NUNES, Benedito. Apresentação. In: NUNES, Benedito (Org.). Evolução da poesia brasileira. Salvador: Fundação Casa de Jorge Amado, 1993b. p. 11-14

NUNES, Benedito. $O$ trabalho da interpretação e a figura do intérprete na literatura. In: PROENÇA FILHO, Domício (Org.). Literatura brasileira: ensaios, criação, interpretação e leitura do texto literário. São Paulo: Norte, 1986a. v. II, p. 73-80.

NUNES, Benedito. A obra poética e a crítica de Mário Faustino. Belém: Conselho Estadual de Cultura, 1986b.

NUNES, Benedito. A poesia de Mário Faustino. In: NUNES, Benedito (Org.). Mário Faustino: poesia completa, poesia traduzida. São Paulo: Max Limonad, 1985. p. 19-46.

NUNES, Benedito. Introdução ao fim. O Província do Pará, Belém, 31 jul. 1966a. Literatura, Caderno 3, p. 2.

NUNES, Benedito. A poesia de Mário Faustino. In: NUNES, Benedito (Org.). Poesia de Mário Faustino. Rio de Janeiro: Civilização Brasileira, 1966b. p. 3-35.

NUNES, Benedito. $\bigcirc$ Homem e sua hora. Jornal do Brasil, Rio de Janeiro, 5 ago. 1956a. Livro de Ensaio, Caderno 2, Suplemento Dominical, p. 10.

NUNES, Benedito. $\bigcirc$ Homem e sua hora (conclusão). Jornal do Brasil, Rio de Janeiro, 12 ago. 1956b. Livro de Ensaio, Caderno 2, Suplemento Dominical, p. 6.

NUNES, Benedito [sob o pseudônimo de J. Afonso]. Dez poetas paraenses. Folha do Norte, Belém, 31 dez. 1950. Suplemento Arte-Literatura, p. 1-3.

PESSOA, Fernando. Sá-Carneiro. In: PESSOA, Fernando. Obra poética. Rio de Janeiro: Aguilar, 1969. p. 583-584.

NUNES, Benedito. Crivo de papel. São Paulo: Ática, 1998. 283 p.

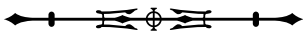

